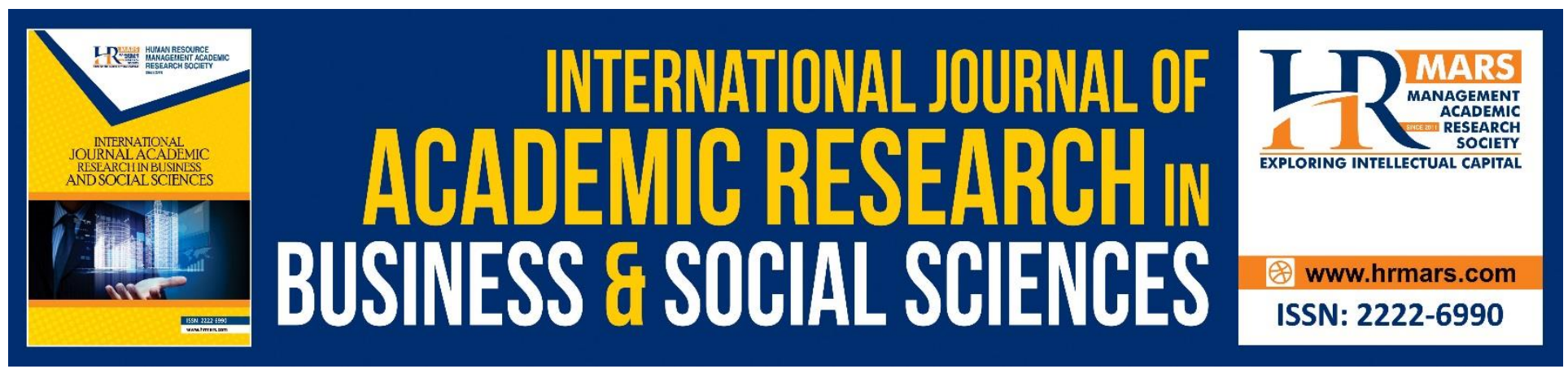

\title{
Al-Akhlaq (Ethics) Perceptions in Islam: A Textual Interpretation through Imam Muhammad Al-Ghazali
}

Mohammed Muneer'deen Olodo Al-Shafi'i, Mohd Safri Ali, Engku Ibrahim Engku Wok Zin, Abdulsoma Thoarlim

To Link this Article: http://dx.doi.org/10.6007/IJARBSS/v8-i10/4737 DOI: $10.6007 /$ IJARBSS/v8-i10/4737

Received: 17 Sept 2018, Revised: 11 Oct 2018, Accepted: 27 Oct 2018

Published Online: 31 October 2018

In-Text Citation: (Al-Shafi'i, Ali, Zin, \& Thoarlim, 2018)

To Cite this Article: Al-Shafi'i, M. M. O., Ali, M. S., Zin, E. I. E. W., \& Thoarlim, A. (2018). Al-Akhlaq (Ethics) Perceptions in Islam: A Textual Interpretation through Imam Muhammad Al-Ghazali. International Journal of Academic Research in Business and Social Sciences, 8(10), 315-329.

Copyright: (c) 2018 The Author(s)

Published by Human Resource Management Academic Research Society (www.hrmars.com)

This article is published under the Creative Commons Attribution (CC BY 4.0) license. Anyone may reproduce, distribute, translate and create derivative works of this article (for both commercial and non-commercial purposes), subject to full attribution to the original publication and authors. The full terms of this license may be seen

at: http://creativecommons.org/licences/by/4.0/legalcode

Vol. 8, No. 10, 2018, Pg. 315 - 329

http://hrmars.com/index.php/pages/detail/IJARBSS

JOURNAL HOMEPAGE

Full Terms \& Conditions of access and use can be found at http://hrmars.com/index.php/pages/detail/publication-ethics 


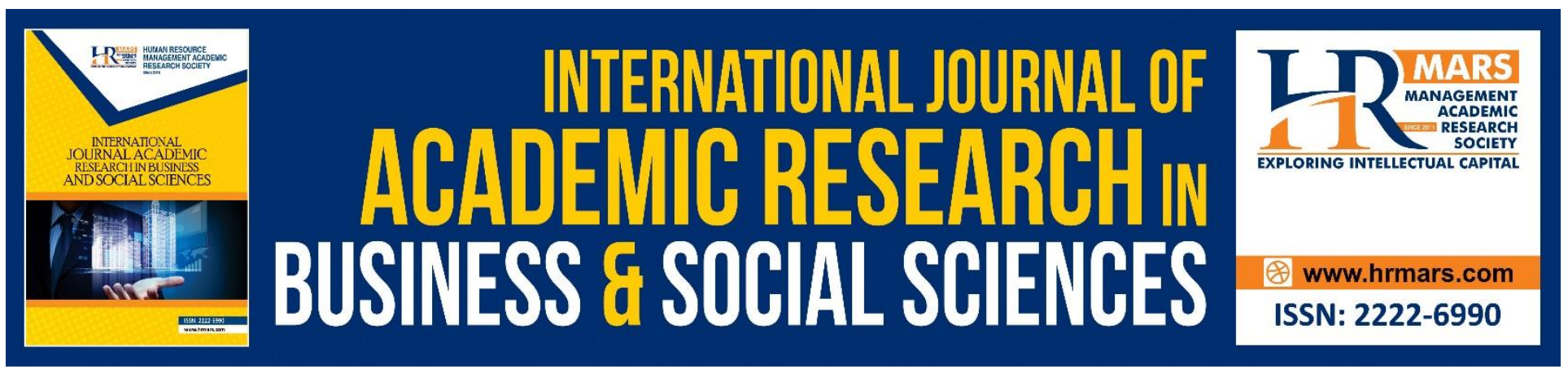

\title{
Al-Akhlaq (Ethics) Perceptions in Islam: A Textual Interpretation through Imam Muhammad Al-Ghazali
}

\author{
Mohammed Muneer'deen Olodo Al-Shafi'i ${ }^{1 *}$, Mohd Safri Ali ${ }^{1}$, Engku \\ Ibrahim Engku Wok Zin ${ }^{1}$, Abdulsoma Thoarlim² \\ ${ }^{1}$ Department of Usuluddin, Faculty of Islamic Contemporary Studies (FICS/FKI), Universiti Sultan \\ Zainal Abidin (UniSZA), Gong Badak Campus, 21300 Kuala Nerus, Terengganu, Malaysia. \\ ${ }^{2}$ Department of Shari'ah, Faculty of Islamic Contemporary Studies (FICS/FKI), University of Sultan \\ Zainal Abidin (UniSZA), Gong Badak Campus, 21300 Kuala Nerus, Terengganu, Malaysia. \\ *Correspondence: posiy2k@yahoo.com, mmolodo@unisza.edu.my.
}

\begin{abstract}
Islam contains a general code of conduct; there is neither much doubt nor disagreement on this. That Islam as both a religion and way of life encompasses all religious issues and affairs affecting human's life is also a fact unchallenged by those of consummate mind. One important aspect of all facets of Islamic discussions, that upon which all arguments sprout and agreements are either diverged and/or reached, that which for its effectiveness also relies on intellectual foundation, is al-Akhlaq (the Ethic). Ethic cum conduct is pertinent in Islamic religious facets. It could be interpreted in many ways and forms; its perception differs from one to the other, and sometimes within an individual, but seldom from one religion to the other. This is an area on which the paper is concentrated. This paper thus seeks to explore the meaning of ethics and the perceptions it has in Islam through the major writings of Imam Muhammad al-Ghazaali, an undeniably sounding ethical name among all noble Muslim scholars. It is also the aim of the study to expatiate the importance of ethic in jurisdiction according to al-Ghazaali. The study commonly employs qualitative library approach in collecting and analyzing the data. The study maintains that al-GhazélÊ's concept of ethics, if carefully applied on most contemporary issues, suffice and proffer long-lasting solutions to various problems intellectually, mechanically, and technically facing the Muslim nations.
\end{abstract}

Keywords: Al-Akhlaq, Ethic, Islam, Imam Muhammad al-Ghazaali, Perceptions.

\section{INTRODUCTION}

Al-Akhlaq, the plural form of al-Khuluq in Arabic language, is literally synonymous to 'al-Sajayaa' (habits), 'al-Tabaai" (natures), 'al-Muruaat' (behaviours), 'al-'Aadaat' (customs), and 'al-Adyaan' (religions and/or ways of life). There are various opinions to the rightful interpretation of Khuluq in English language, while some refer to it as conduct, others call it morality, and some others ethics, 
behaviours, disciplines, practices, and so on, but the scope of this paper falls outside the realm of disagreements and approval of the meanings. The most appropriate and equivalent interpretation this paper, as in other similar papers on this topic, adopts is 'Ethic'. And as we adopt khuluq as 'ethic' so we approve al-Akhlaq undoubtedly as 'Ethics'. Ethic, as known today, was derived from Latin word 'ethicus' and Greek word 'éthikós', indicating 'moral character' in relation to 'êthos' (custom, habit). It is by definition a moral principle that governs one's behavior or the conducting of an activity, moral principles by which one is guided; it is the branch of science that deals with moral principles.

Ethics is found employed synonymously to moral code, morals, morality, values, rights and wrongs, principles, ideals, standards (of behavior), value system, virtues, and/or dictates of conscience, among others. It is the study of standards of right and wrong; that part of science and philosophy dealing with moral conduct, duty, and judgement. It is formal and professional rules of right and wrong, a system of conduct or behavior, the seat of which is the hearts, and not the minds. It is thus not accidental, but rather coincidental, to see Hans Wehr referring to it as 'the innate peculiarity' (Barnhart, 1966; Qafisheh, 1997; Rahman, 2010; Salmone, 1978; Catafago, n.d; Wehr 1976; Pearson, 2008; and Al-Shafi'i and Ali, 2017).

Islam as both a deen and a perfect way of life encompasses all facets of all creatures, living or non-living. Islam institutes a living order, al-Akhlaq, built on a solid foundation, al-'Aql, with four basic importance closely related to maintainance (tahseen) and maintenance (siyaanah), meaning 'safeguarding and protecting'.

The first of the four basic importance of al-Akhlaq is the maintainance (protecting and safeguarding) of one's cordiality to Allah SWT (siyanah wa tahsin al-'Alaqah bayn al-'Abd wa Rabih). This is to make true the primordial consciencual agreement between one's consciencual existence and Allah SWT as stipulated in alastu bi Rabikum and further in the Divine decree 'wa qada Rabbuk alla ta'budu illa iyyah'.

The second of the four basic importance of al-Akhlaq is the maintainance of cordiality with oneself (siyanah wa tahsin al-'Alaqah bayn al-'Abd wa nafsih). Nasihah is best given and taken by and from the one who practically possesses such, faqid shay'in la yu'tih, so says the adage. This is in the context of '...qu anfusakum wa ahlikum al-Nar'.

The third of the four is the maintainance of cordiality with one's fellow beings (siyanah wa tahsin al-'Alaqah bayn al-'Abd wa ghayrih min al-Bashar). It starts from one's parent as depicted in '...wa bi al-Walidayn ihsanan', then to one's close relatives, such as siblings, and extended relatives such as uncles, sisters, aunties, in-laws. Ones' neighbours are not excluded in this circle, because they are one's 'mujawir'.

The fourth, and the last, is the maintainance of cordiality to non-human beings (siyanah wa tahsin al-'Alaqah bayn al-'Abd wa ghayrih min ghayr al-Bashar). This includes all domestic animals and other non-living organisms in the environment in which one inhabits. Stoning and killing animals 
INTERNATIONAL JOURNAL OF ACADEMIC RESEARCH IN BUSINESS AND SOCIAL SCIENCES Vol. 8, No. 10, Oct. 2018, E-ISSN: 2222-6990 @ 2018 HRMARS

unjustifiably are outside the ethical realm, and vandalizing government cum public properties is unethical.

The most important of the four is siyanah wa tahsin al-'Alaqah bayn al-'Abd wa Rabih, while the other three lead to it in relevance. All ethical values should be for the purpose of attaining the everlasting and eternal bliss, as maintained by al-Farabi that the ultimate goal of human existence and deeds is to attain supreme happiness (al-Sa'adah al-Qaswa), which he relates with the absolute good (al-Khayr al-Mutlaq), '...that which is chosen and desired for itself and is not chosen, at any time whatsoever, for the sake of anything else. All else (other things) is chosen for its use in the attainment of happiness. It should be noted here that the happiness referred to is 'the Ultimate Good', which in turn is 'God'. Thus, all ethical values and relationships should lead and direct towards the everlasting bliss' attainment in God (Dunlop, 1961; Bakar, 2006; Shihadeh, 2006; Al-Attas, 2001; 'Abduh, 1999; and Al-Shafi' $i$ and Ali, 2017). The instructions cum ethical injunctions should start and end with 'Thou shall not set up any other god with Allah in worship, for if ye do, then thou shall forever remain condemned as ungodly, and be forsaken by Him utterly' and 'Thou shall not set up in worship any other god with God. If ye do, then thou shall be cast into Hell, deservedly blameworthy, forever banished' respectively, indicating that all starts and ends for the sake of Allah SWT to be accorded a reward.

\section{IMAM MUHAMMAD AL-GHAZAALI}

Al-Zabidi (1989) and Ahmad Shams al-Din (1411AH/1990CE) maintain that "law kana nabiyyun ba'd al-Nabiyy la kana al-Ghazaali" (If there possibly could be another prophet after Prophet Mohammed SAW, it could surely have been al-Ghazaali). This is not strange, based on Muhammad al-Ghazaali's pedigree as one of the most highly celebrated scholars in the Islamic historical thought. His incomparable life and works remain central in jurisprudence, mysticism, philosophy, ethics, and theology. The voluminous books and philosophical opinions on ethics he leaves behind are the result of a probing mind in the quest for knowledge meant for a well-balanced and suitably conducive society he had hope for. He says in his autobiographical work, the Deliverance from error, that:

The quests for grasping the real meaning of things, as they really are, is indeed my habit and wants from my early years and in the earliest stage of my life. It is an inherent, natural disposition placed in my makeup by Allah Most High, not something due to my self-choice and contrive. As a result, the fetters of servile conformism fell away from me, and inherited beliefs lost their hold on me, since when I was quite young (alGhazaali, 1994CE/1415AH; Akdogan, 2008).

He is Muhammad al-Ghazaali, popularly referred to as Imaam Abuu Haamid al-Ghazaali, Ibn Muhammad Ibn Ahmad al-Tuusi. Although he was originally a Persian born in Tus Khurasan near Meshhad in today's Iran in 450AH/1058CE, his writings are overwhelmingly written in Arabic, the most prevalent language of learning and civilization of the time. He maintains the title of respect Hujjah al-Islam (Proof of Islam) for the role he plays in defending Islam against the trends of thought that exist at all time (al-Subki, 1990). 
$\mathrm{He}$, and his younger sibling Ahmad, was entrusted to the care of a Sufi friend of his father whom he asked to spend whatever little asset/property he left behind on educating them. But when the property was exhausted, the Sufi asked them to join a school so that they might subsist. AlGhazaali would later ethically confessed, in his famous phrase, saying: "Talabnaa al-'llm li ghair Allah, fa abaa an yakuuna illa li Allah" -we acquired knowledge for other than Allah (for worldly matters), but (it) refuses to be but for Allah (for heavenly matters) (al-Din, 1411AH/1990CE; al-Subki, 1990).

He lived in what might be described as a post-golden age context. The production of the exact sciences faded away, the Islamic state had grown into a massive caliphate that faced disintegration as the provincial governors gained power. Just before al-Ghazaali was born, the institution of the Sultan was introduced or rather forced on Baghdad. The year 450AH marked the first time a split in power took place between the Sultan, who was the actual ruler, and the Caliph whose role was reduced to dignitary functions (al-Din, 1411AH/1990CE). It was a classic case of a wealthy and powerful civilization that lost track of its sense of direction and lost sight of its roots, its source of power. The indulgence in material life had led many celebrities to abandon public life and to live in seclusion. It was a search for a meaning of life in asceticism. Sufism thrived before al-Ghazaali was born and he ultimately subscribed to the mystics' path.

His status in Islam ranges from being the hujjah al-islam (Proof of Islam) and the mujaddid alQarn al-khamis al-hijri (revamper of the $5^{\text {th }}$ century $\mathrm{AH}$ ) to being tagged a non-believer by some contemporary scholars. The unfortunate gap between the two positions reflects the war that ensued between the Sufis and the Salafis, a war that is almost as old as Islam itself. Al-Ghazaali leaves behind him a great number of books and treatises, one of the most celebrated of which is the 'Ihya' 'ulum al-din (Revival of Islamic Sciences). He is a scholar per-excellence whose lectures at the Nizaamiyah school of Baghdad recorded the attendance of some hundreds of notable scholars such as al-Qadi Abu Bakar Ibn al-'Arabi who was a Maaliki, al-Khatabi and Abu al-Wafa' Ibn 'Aqil who were Hambalites. In reflection of the influence of al-Ghazaali on the Latin world, Manuel Alonso lists fortyfour medieval philosophers and theologians who hold al-Ghazaali in high esteem, it includes Thomas Aquinas who refers to Maqasid al-Falasifah thirty-one times.

\section{STATEMENT OF PROBLEM, QUESTIONS AND OBJECTIVES}

The importance and significance of al-Akhlaq in mortals' affair has been an age-long discussion among scholars; religious or non-religious, traditional, philosophical or modern. Discussing al-Akhlaq in the light of its perception in Islamic works of selected scholars such as al-Ghazaali would be valuable in understanding its concept.

In the light of this paper, three distinctive questions, leading to its objectives and significance, are addressed; what is al-Akhlaq, and how is it defined in various dictionaries, who is al-Ghazaali and how does he perceive al-Akhlaq, and what does al-Ghazaali say with regard to al-Akhlaq and religious injunctions. 
INTERNATIONAL JOURNAL OF ACADEMIC RESEARCH IN BUSINESS AND SOCIAL SCIENCES

Vol. 8, No. 10, Oct. 2018, E-ISSN: 2222-6990 @ 2018 HRMARS

The major objectives and focuses of the paper are to explain the concept of al-Akhlaq, examine al-Ghazaali's scholastic views and religious perceptions on al-Akhlaq, and clarify alGhazaali's saying with regards to al-Akhlaq and religious injunctions.

\section{METHODOLOGY}

This study is based on a library research, employing suitably, a qualitative approach. In other words, the main method of data collection for this study is through the library research, and the methodology is the study and review of primary and secondary sources, documents from journals, books, and official documents including any report relating to the concept of al-Akhlaq, most especially through the writings of Imam al-Ghazaali.

\section{DISCUSSIONS AND ANALYSIS}

\section{AL-'AQL (THE INTELLECT) AND AL-AKHLAQ (ETHICS)}

The intellect it is popularly agreed and approved as a base for all valid knowledge; virtually, nothing escapes the authority of the intellect, and so is the Ethics. For one to be of noble and praiseworthy ethics; morality, character, behavior, conduct, and the likes, one must be of consummate intellect. The purpose of the intellect is to avoid one from proceeding in one's lustful wants and guides one to the right path, as the one who is intelligent is the one who observes Allah's dos and don'ts. Ibn Qayyim, in his Madarij al-Salikan, volume one page 446, maintains that the livelihood of the intellect (hayah al-'Aql) is sound perception (sihhah al-idrak), strength and profundity of understanding (quwwah al-fahm wa jawdatih), and the realization of the benefit or harm there is in a thing (tahqquq al-'intifa' bi al-Shay' aw al-Tadarrur bih). It is a divine light Allah SWT gifts to whom he so wills from amongst His creations and it is in accordance to mortals' disparity in the strength or weakness of that divine light; its existence or its nonexistence, that their disparity in mentality, comprehension, and perception could be recognized. The relationship between the intellect and the heart is like that of the sight to the eye.

In his al-Mankhul min ta'liqat al-Usul (Purified selections from comments on the principles) alGhazaali defines the intellect as "the criterion (sifah) which prepares the talented [person] to perceive sciences (knowledge) and to comprehend the cognizable (al-Ma'qulat)" (al-Ghazaali, 1998CE/1419AH). To define the intellect, according to al-Ghazaali, we have to take into consideration certain elements. The intellect in his view has three preambles (inputs) and one outcome (an output). He says, the interpretation of which is: Its (the intellect's) preambles (muqaddimat) are hearing (sama ), awakening/awareness (tayaqquz), and remembrance/recollection (dhikr), while its proceeds is knowledge $\left(\mathrm{al}-\mathrm{I}^{\prime} \mathrm{l} \mathrm{m}\right)$, for he who hears awakens, who awakens remembers/recollects, and [it is he] who remembers [that] reasons (tafakkar); [it is he] who reasons [that] knows, and who knows works [with what he knows] if it is a [kind of] knowledge meant to be practiced; if it is knowledge for its [knowledge] sake, he succeeds, and success is the utmost goal [of the intellect] (al-Ghazaali, n.d).

The intellect is of various categories. At least four different categories of the intellect can be distinguished. One is wahbiy (gifted), the next is kasbiy (acquired), the other is warthiy (inheritted), and yet another is 'amaliy (practical). Another possible unclear category is talabiy (learnt), which 
INTERNATIONAL JOURNAL OF ACADEMIC RESEARCH IN BUSINESS AND SOCIAL SCIENCES Vol. 8, No. 10, Oct. 2018, E-ISSN: 2222-6990 @ 2018 HRMARS

qualifies a sub-category of kasbiy mentioned earlier, but the distinction lies in the literal extracted meaning of each; the first being informal (hand-work wise) while the latter is formal (intellectual wise).

Thus, an intelligent one is the one who is able to control, and guide, oneself away from its lustful wishes. This is so because $a$ l- $^{\prime} \mathrm{Aql}$ (the intellect) is so called because it deprives one from falling into perils; it is the only distinction which distinguishes man from other living organisms. Ibn al'Anbaari maintains that an intelligent man is the one who can control his own affairs and views, while the less-intelligent is the one who depends on others in handling his affairs and opinions.

The intellect, it is argued, is either in the skull or in the heart. But the reality here is that it is in both and at the same time, none of the two places can be void of the intellect for even a millisecond and still remains the same. The intellect, when imagined in the skull, represents thought and contemplation, and it is the representation of wishes and desires when related to the heart. Thus, it could be right to say that 'the heart is the abode of guidance while the skull is the abode of thought'. Either located in the heart or the skull, the intellect is a spiritual substance created by Allah SWT and hung to the human body; it is not like any physical parts or organs of the body that could be imagined. It is one of the greatest bounties through which one possesses the ability to perceive one's environs, and also to comprehend that which is imperative on one to do and that which one should avoid. It is through the intellect that one realizes one's self-existence and one's Lord in one hand, and to build and maintain a cordial relationship with those around one, living or non-living organisms. While living with others in cordiality, an intelligent one learns through the mistakes of others in his surroundings while the stupid one allows himself be used as an example. Some numerous Qur'anic verses alGhazaali is found quoting are, but not limited to: "...indeed, in all of this there are sure signs 'of One Creator' for a people who would use their intellect to understand" (surah al-Ra'd: 4, in Hammad, 2009); "...Thus do We make distinct the signs for a people who would use their intellect to understand" (surah al-Rum: 28, in Hammad, 2009); "So such are the parables We set forth for the benefit of people. Yet none intellectually comprehend them but the people of knowledge, the contemplative ones" (surah al-Ankabut: 43, in Hammad, 2009); "He gives intellectual wisdom to whomever He so wills. And whoever is given intellectual wisdom has truly been given much goodness. And none is truly mindful of this but those who are endowed with consummate intellect (discretion and understanding) and so heed admonition" (surah al-Baqarah: 269, in Hammad, 2009); and in surah al-Ma'idah: 100, where Allah SWT says "Say to humanity: The corrupt and the good are not equal, even if the profusion of corrupt ways seems pleasing to you. So be conscious of Allah, o you people of consummate intellect (discretion and understanding) so that you may be successful" (Hammad, 2009).

Sayyidah 'Ayishah $R^{\prime} A$, in Rawdah al-Muhibbin: 38, was reported to have said: "He has succeeded, the one whom Allah has blessed with intellect". Abu Hatim also said: "the most virtuous gift of Allah to His servants is the intellect". It was also said that "The best portion Allah gives a mortal is his intellect, there is nothing compared to it in all goodness. And if The Beneficent (Allah SWT) has perfected for a mortal his intellect, then all his ethics and moralities have been perfected. For the person could dwell among people provided he is intellectually sound, although he might be less privileged in sustenance". Al-Mawardi is reported to have said that "...the intellect is the tool to 
INTERNATIONAL JOURNAL OF ACADEMIC RESEARCH IN BUSINESS AND SOCIAL SCIENCES

Vol. 8, No. 10, Oct. 2018, E-ISSN: 2222-6990 @ 2018 HRMARS

understanding realities of things..., it is the only distinction between man and other living organisms, and the one who possesses it is referred to as 'the intelligent one'".

Thus, in relation to ethics, the intellect must be related well with moralities. This is so because one's ethics and moralities could be a direct pictorial representation of one's intellect. The intellect that is void of morality is like a barren tree, and that with morality is like a fruitful tree. Virtue is reflected through the intellect and ethics and not through tribal pedigree of origin and tribe, as ethics is a means to all virtues and empowerment to all shari'ah (law) and regulations. There is no pride for one whose morality and character are bad and worthless.

\section{THE SCHOLARS AND THE INTELLECT}

Scholars are of three categories with regard to the importance and the preference of the intellect. Two of the three categories seem extreme, while one is moderate. The first of the two extreme is the category of scholars who maintain regard the intellect as the only primal source. To this category of scholars, the intellect is self-dependent and independent of al-Shari'ah, it requires no heavenly direction as it suffices as an All-in-All. To this category, there is no connectual relation of the intellect to revelation, none interfere with the other.

The second category of the first two extremes is the category of scholars maintaining condemnation and valuelessness of the intellect. To this category, no representation whatsoever is attributed to the intellect, and the intellect lacks all worthy and trusts in any judgement. It is the conviction of this category of scholars that all credence is awarded the revealed sources of information and knowledge. The revelation therefore should be readily utilized exactly as it is, as no further intellectual interpretation is required. Thus the intellect has no role to play in the expatiation of the revelation because the revelation is self-explanatory and does not require detail elaboration or clarification from the intellect. This category of the scholars is the direct opposite of the first; they have both refused the interconnection and interrelation of the intellect and the revelation.

The third category is the category of majority of the scholars; the moderate path scholars, who neither maintain the intellect as All-in-All nor Nothing-at-All. To this set of scholars the intellect is an important condition and aspect in the comprehension of things; it is a condition in human responsibility (al-Taklif) and the comprehension of the revelation is done through intellection, as the Qur'an in surah al-Nisa': 82 says: "Will they not, then intellectually reflect on the meaning of the Qur'an? If it had been from other than Allah, they would, most surely, have found in it much discrepancy". This particular group of scholars maintain, among others, that the intellect could not be self-reliant but in need of al-Shar' (the Divine law/Revelation), the intellect is there to certify and ascertain all information given and that shall be given by the revelation, and that $a$ l-Shar' $u$ (the revelation) contains intellectual evidences, explains it and informs of it. This is the path upon which Islamic ethics is based. There is no representation of ethics in the one who lacks the intellect and there is no religion for the one who lacks morality. 
INTERNATIONAL JOURNAL OF ACADEMIC RESEARCH IN BUSINESS AND SOCIAL SCIENCES

Vol. 8, No. 10, Oct. 2018, E-ISSN: 2222-6990 @ 2018 HRMARS

\section{AL-GHAZAALI'S CONCEPTUAL VIEW ON ETHICS}

It is pertinent from the onset to clarify that al-Ghazaali uses two synonymous words almost simultaneously, he uses the word ' $a d a b^{\prime}$ ' to mean ' $k$ huluq' and vice-versa. In his discussion about the virtue of companionship and brotherhood, its conditions, stages, and benefits, he says that 'companionship (al-Ulfah) is a proceeds of good ethics (husn al-khuluq) while dividence (al-Tafriqah) is a proceeds of bad ethics (su' al-Khuluq)'. This is so because husn al-Khuluq necessitates affection, companionship and understanding, and su' al-Khuluq breeds enemity, envy, and disparity. The more praiseworthy the source is the more the proceeds is praiseworthy; the virtue of good ethics is not hidden in religious discussions for with it Allah SWT has praised His noble prophet SAW when He SWT says: "For, indeed, you are, most surely, a man of outstanding character" (surah al-Qalam: 4), to which the Prophet SAW corresponded by saying: "the most of through which people would be granted into Jannah is the consciousness of Allah and good ethics". Usamah bin Sharik reports that he and some other companion inquired from the Prophet SAW as to 'what is the best gift given to people' to which the Prophet SAW responded 'a good ethics'. The prophet SAW complimentarily says that he was raised to perfect good ethics, and says: "the weightiest of which would be measured on the day of judgement is husn al-Khuluq" to the extent that "Allah SWT would not perfect the creation and ethics of a person and then taste him the hell". In a friendly conversation between the Prophet SAW and Abu Hurayrah, the Prophet SAW enjoined Abu Hurayrah with husn al-Khuluq, to which Abu Hurayrah inquired 'what is husn al-Khuluq oh Messenger of Allah?', and the Prophet SAW replied: 'relate with those who have severed their relationship from you, pardon those who have oppressed you, and give those who deprive you'. It is good to know that some of the proceeds husn al-khuluq is companionship and lack of loneliness (Al-Zabidi, 2009). Thus, ethics is an expression of an act situated in the soul (mind), from which deeds sprout easily and simply and without necessitating a pre-thought and plan. If the proceed of the act that sprout therefrom is 'good', then the act is referred to as 'good ethics', but, on the other hand, if the proceed of the act that sprout therefrom is 'bad', then the act is referred to as 'bad ethics'. Ibn Manzur, in his Lisan al-'Arab, volume 1 pages 86-87, while referring to the surah al-Qalam: 4 (For, indeed, you are, most surely, a man of outstanding character), says that al-Khuluq or al-Khulq is al-Din, wa al-Tab'u wa al-Sajiyyah (the character mentioned in the Qur'anic verse means the religion as a way of life, the primordial nature upon which man was created, and the habit of man. It signifies from the above that ethics is an integral part of al-Din and anyone who lacks ethics also resultantly lacks the $d i n$.

In huquq al-Ukuwwah wa al-Suhbah i.e the rights to companionship and friendship, alGhazaali says that the tie of brotherhood is a bi-relationship such as that of marriage (Nikah), and as there are necessitating rights and rules in nikah, so there are in brotherhood. He mentions eight distinguishing, but closely related, ethical relations in brotherhood, companionship and friendship (al-Zabidi, 2009).

First is the wealth cum property. The prophet SAW say: "the similitude of two brothers is that of two palms cleaning each other" for they help and assist each other and share everything with the same aim and objective. There are three major categories in relating with each other in property/wealth. The lowest of the three categories (adnahah) is to regard a partner as a slave, 
servant or maid, in which case you take care of his need from your left-over wealth and without letting him ask before you give. The middle of the three categories is to treat your partner and regard him as yourself, just the same way the righteous ones do when they share their trousers with one another. The highest category of the three is to prefer your partner over yourself in treatment. This is the highest rank of preferences (al-Zabidi, 2009).

Second is self-willing assistance rendered to solving one's partner problem without been asked, and placing it over individual preferences. As in the previous relation, there are three levels here also. The lowest is the assistance rendered after the companion has asked, the middle is that rendered when he is perceived to be in need, and the highest is the one rendered without you feeling it and without the other partner knowing (al-Zabidi, 2009).

Third is maintaining a silent-tongue. One should control one's tongue from talking about one's partner's defects, either in his presence or in his absence. One should ignore a partner who orally offends one, and should not interfere with his secrets, and one should avoid publicizing anything one knows about one's partner by devouring it to one's other friends (al-Zabidi, 2009).

Fourth is maintaining a spoken-tongue. In the same way that you are not supposed to talk evil about your partner, you should be ready to acknowledge all goods that come through and from him. One benefit of brotherhood is sharing both the hard and the ease. The Prophet SAW says: "when one of you is inclined towards the other let him (the liker) informs him (the liked). 'Aliy R'A says: "the one who could not appreciate his brother on good intention would not appreciate his good deed". One should project to the partner what one wishes the partner to project to one (al-Zabidi, 2009).

The fifth is overlooking of mistakes and misconducts. One's partner could not be free of either religious lapses or lack of sincerity in brotherhood. If the lapses is religious and it is repetitious, you have to be careful and lenient in advising him towards the right, until he is back to uprightness. And if his lapses are insincerity towards you, the best thing to do is utmost patience and perseverance. If he apologizes to you, honestly or otherwise, accept his apology with sincerity. The Prophet SAW says: "whoever refuses to accept his brother's apology is committing the same sin as the one who commits great sins". He SAW also says: "A mu'min who is fast in getting angered should be fast in getting appeased" (al-Zabidi, 2009).

The sixth is the act of praying for one's partner, dead or alive. Ethically, prayer should be offered for one's partner, whether he is alive or dead, what he likes for himself, his family, as well as everything related to him, just as one would do for oneself without any difference or disparity. This is so much required because prayers offered on behalf of one's partner are in actual sense prayers offered to oneself. The Prophet SAW say: "when a man prays for his fellow without him knowing, the Angel says to him: "and to you is also what you have asked for your fellow". In another narration, "...Allah SWT would say: with you I will start the acceptance of the prayer, oh my servant". It is reported in another hadith that one's prayer, which would not have been answered, would be 
answered through one's prayer for one's fellow, for the prayer one offers for one's fellow in his absence would never be rejected (al-Zabidi, 2009).

The seventh ethical relation is fulfilment of promise and sincerity. The meaning of fulfilment and sincerity here is the continuity of affection and staying firmly to it until death, and to extend same to the fellow's progeny and other friends even after death. Love and affection is meant to be everlasting, if it is severed before death that is a loss of deeds and actions, and if it is severed after death that is a loss of reward. It is not part of fulfilment and sincerity approving one's fellow's wrongdoings on the right of Allah SWT, but rather fulfilment and sincerity lies in lambasting him until he repents (al-Zabidi, 2009).

The eighth, and last, of the ethical relations is leniency, and lack of affectation and compulsion. One should not emburden one's fellow with that which he could not withstand. The Prophet SAW says: "Me and the righteous ones of my ummah are not concerned with (have nothing to do with) compulsion. He says: "A man is judged based on the religion of his fellow, and there is no benefit in a fellow who fails to treat you as well as you treat him" (al-Zabidi, 2009). These are the eight ethical relations projected by al-Ghazaali in one-on-one relationship, and they should by large be extended to moral institutions of learning and the societies.

In the book of livelihood and Prophetic ethics (Kitab adab al-Ma'ishah wa akhlaq alNubuwwah) of al-Zabidi (2009), al-Ghazaali says:

the physical (outer) moralities are the traces of the inner moralities, the physical movement of the outer parts of the body is the result of the inner movement of the mind, actions are the proceeds of the ethics, moralities are the base of all information and the secrets of the hearts; it is the plot (farmland) of all actions and its later development. It is the lights of the secret inner parts that brighten the physical ones to beautify and glow it, it replaces its physical irregularities with the inner beauties. The one whose heart fears not, such's physical parts would fear not, and the one whose hearts is not the abode of the divine lights, such's physical appearances would lack the splendor of the Prophetic moralities and ethics (al-Zabidi, 2009).

Thus, ethics could be divided into two broad categories, namely, good, praiseworthy, virtuous ethics and bad, blameworthy, reprehensive ethics. Every human has the tendency and freedom of choosing whether to be good or to be otherwise, but instinctively, man is made to know whether he is right or wrong because of the gift of the intellect he was primordially endowed with, as ascertained in surah al-Insan: 3 that "indeed, it is We alone who have shown him (man) the way to be either grateful (right) or ungrateful (wrong)" (Hammad, 2009).

\section{AL-GHAZAALI'S CONDEMNATION OF ANGER, HATRED, AND ENVY}

Anger, hatred, and envy are anti-ethical; they are against the primordial nature of creation, and anyone described with any of the three lacks primordial ethics. Anger is by interpretation a portional 
flame extracted from the burning fire that flares on the hearts of those who deserve it; the flame is buried inside the heart just as the black-burning-charcoal beneath the ashes. This flame is prevailed through the arrogance inscribed in the heart of all the stubborn-arrogant ones, just as hot stone is extracted from metal. Two major proceeds of anger are hatred and envy, which are destroyer of those who are destructed, the source of which is the piece when it is good the whole body is good and when it is spoilt the whole body becomes spoilt. And if hatred, envy, and anger push a person into the station of damage, such a person is in dire need of knowing his mistakes and misdeeds so that he would be able to avoid and prevent them from gaining balance in his heart. The knowledge of mistakes and misdeeds is not enough for one who does not know how to avoid ways of falling into the mistakes and misdeeds.

Allah SWT condemns the unbelievers' display of enmity stemming out of anger and calls it evil, and He SWT praises the believers for their display of tranquility. This is exemplified in surah al-Fath: 26 where Allah SWT says: "Behold! Those who disbelieved induced in their own hearts hot indignation at Hudaybiyyah -the indignation of pagan ignorance- to block you from the Sacred Mosque. So Allah sent down His tranquility upon His Messenger and upon the believers, who stayed their hands. And thus Allah caused them to adhere to the imperatives of the word of piety -for they were most worthy of it and entitled to it. And ever is Allah all-knowing of all things" (Hammad, 2009). With regard to anger as anti-ethic, 'Abdullah ibn 'Amr reported that he asked the Prophet SAW about that which could safe him from the anger of Allah SWT and the Prophet SAW replied: "la taghdab" avoid getting angry. Ibn Mas'ud also reports that the Prophet SAW once asked us saying: "what do you regard as strengthful among you", to which we replied: "the one who no one can over-power". Then the Prophet SAW says: "That is no the strengthful, but he is the one who controls himself during anger". This is meant to say whoever controls his anger, Allah SWT will protect his human-privatedignity (al-Zabidi, 2009).

There are many causes of anger, some of them are: arrogance, pride, proud, indignation, forgetfulness, joking, humoring, mockery, underrating, opposition, treachery, strong wants for wealth and fame; they are all together furious and indignant ethics legally, and there is no escape from anger in the presence of all the afore-mentioned causes (al-Zabidi, 2009). All the abovementioned causes of anger, hatred and envy could only be corrected and counteracted through seeking for virtuous and praiseworthy ethics in the company of religious sciences and understandings that lead to everlasting bliss; solving them requires religious training and education (al-Zabidi, 2009).

Mahmud al-Warraq summarizes ways out of the defects and dangers of anger in the following poetic stanzas. He uses the stanzas to explain the three types and/or categories of people and the ways of relating with all the three kinds. He says:

I will addict myself to forgiving all wrong-doers;

No matter how numerous his offences towards me is.

People are but one of these three categories;

The superior, the less-privileged, and the moderates. 
As for the superior to me, I accord to him his worths;

And I would follow in him the Truth, for the Truth sustains.

As for the less-privileged to me, when he insults;

I would protect against answering him my dignity, though it hurts.

As for he who to me is a mate, when he offends and errs;

I would prefer perseverance, for wisdom is contained in preference (al-Zabidi, 2009).

All the aforementioned is embedded in the spirit of surah al-Isra': 9, "Indeed, this Qur'an guides humanity to that which is most upright..." and that of surah al-Nahl: 90 "Oh humankind! Indeed, Allah commands the execution of justice among you, and the doing of good to others, and the giving of charity to close relatives. Moreover, He forbids all obscenity and shameful deeds and aggression. He admonishes you with this, so that you may become mindful of His commandments", a similar clarification of which is found in surah al-A'raf: 33 where the Prophet S'AW was instructed to "Say to them: Indeed, my Lord has only prohibited obscenities, whatever of it is manifest and whatever of it is hidden, and all sin, and especially the offense of oppression without any right, and that you associate with Allah that for which He has never sent down any authority, and that you say concerning Allah that which you know not".

\section{CONCLUSION}

This paper has been able to address the stipulated research objective, namely, 'explain the concept of al-Akhlaq', 'examine al-Ghazaali's scholastic views and religious perceptions on al-Akhlaq', and clarify al-Ghazaali's saying with regards to al-Akhlaq and religious injunctions'. In conclusion, alGhazaali's concept, views, and interpretation of ethics is mostly unanimous with that of notable scholars like him, and his views are not antagonizing to that maintained in the Qur'an and hadith. It is highly important to note that al-Ghazaali's reliance on the Qur'an and hadith is clearly unavoidable, all his interpretations circumambulate around that which is divinely maintained. In al-Ghazaali's general interpretation, it could be deduced that al-Akhlaq is the third in rank in Islam, it is third to al'AqI and al-Iman. If this depicts something, it is that faith in Allah SWT comes first, next comes the intellect upon which al-Akhlaq is based.

\section{ACKNOWLEDGEMENT}

Special appreciations to the Research Management, Innovation \& Commercialization (RMIC), Universiti Sultan Zainal Abidin (UniSZA) \& the Faculty of Islamic Contemporary Studies (FKI, UniSZA) for sponsoring the project.

\section{Corresponding Author}

\section{Mohammed Muneer'deen Olodo Al-Shafi'i}

Department of Usuluddin, Faculty of Islamic Contemporary Studies (FICS/FKI), Universiti Sultan Zainal Abidin (UniSZA), Gong Badak Campus, 21300 Kuala Nerus, Terengganu, Malaysia.

Email: posiy2k@yahoo.com,mmolodo@unisza.edu.my. 
INTERNATIONAL JOURNAL OF ACADEMIC RESEARCH IN BUSINESS AND SOCIAL SCIENCES

Vol. 8, No. 10, Oct. 2018, E-ISSN: 2222-6990 @ 2018 HRMARS

\section{REFERENCES}

Al-Qur'an.

'Abduh, M. (1999). Falsafah al-Akhlaq. Cairo: Maktabah Madbuliyy. $2^{\text {nd }}$ edition.

Akdogan, C. (2008). Science in Islam \& The West. Malaysia: International Institute of Islamic Thought and Civilization (ISTAC), International Islamic University (IIUM).

Al-Attas, S.M.N. (2001). Prolegomena to the metaphysics of Islam: An exposition of the fundamental elements of the worldview of Islam. Malaysia-Kuala Lumpur: International institute of Islamic Thought and Civilization (ISTAC).

Bakar, O. (2006). Classification of knowledge in islam: A study in Islamic philosophies of science. Seyyed Hossein Nasr (Forward). Malaysia- KL: ISTAC-IIUM.

Barnhart, C. L. (1966). The world book encyclopedia dictionary. Chicago: Field enterprises educational corporation.

Catafago, J. (n.d). An Arabic and English Literary Dictionary, in two parts, Arabic and English, and English and Arabic. Beirut: Librairie du Liban. $3^{\text {rd }}$ edition.

Al-Din, S. A. (1411AH/1990CE). Al-Ghazaali: hayatah, atharah, falsafatuh. Beirut-Lebanon: Dar alKutub al-'llmiyah. $1^{\text {st }}$ edition.

Al-Din, S. A. (2006). Majmu'ah Rasa'il al-Imam al-Ghazaali, rawdah al-Talibin wa 'umdah al-Salikin, al-Bab al-Thalith wa al-'Ishrun. Lebanon: Dar al-Kutub al-Ilmiyyah. $4^{\text {th }}$ edition.

Al-Ghazaali, M. (1994CE/1415AH). Al-Munqidh min al-Dalal wa al-Mufsih 'an al-'Ahwal. 'Abd alMun'im al-'Ani (ed.). n.p: al-Hikmah.

Al-Ghazaali, M. (1998AD/ 1419AH). Al-Mankhul min ta'liqat al-'Usul (a book on usul al-fiqh). Muhamad Hasan Hitu (ed.). Damascus: Dar al-Fikr. $3^{\text {rd }}$ edition.

Hammad, A. Z. (2008). The gracious Quran: A modern-phrased interpretation in English. USA: Luccent International, LLC, Arabic-English parallel edition. $2^{\text {nd }}$ print.

Pearson, L. (2008). Longman dictionary of contemporary English: the living dictionary. England: Pearson education limited. $4^{\text {th }}$ impression.

Qafisheh, H. A. (1997). NTC's Gulf Arabic-English dictionary. USA: NTC publishing group.

Rahman, A. M. R. (2010). Introduction to Islamic and Buddhist personal ethics. Malaysia-Negeri Sembilan: USIM's Publisher, Universiti Sains Islam Malaysia. $1^{\text {st }}$ printing.

Salmone, H. A. (1978). An Advanced Learner's Arabic-English Dictionary: Including an English Index. Beirut: Librairie du Liban. New Impression.

Al-Shafi'i, M. M. O. \& Ali, M. S. (2017). Al-Akhlaq (Ethics) perceptions in Islam: An interpretation through Mawsu'ah al-Akhlaq of Khalid al-Kharraz. Malaysia, Kuala Nerus: International seminar on Islamic jurisprudence in contemporary society 2017 (ISLAC 2017) "The social harmony through Islamic law". E-Proceeding 1495-1507.

Shihadeh, A. (2006). The teleological ethics of fakhr al-din al-razi. In Islamic philosophy, theology and science: Texts and Studies. Vol. LXIV. H. Daiber and D. Pingree (eds.). Leiden.Bosten: Brill.

Al-Subki, T. A. A. (1990). Tabaqat al-shafi'iyyah al-kubra. Mahmud Muhammad al-Tanahi \& 'Abd alFatah Muhammad al-Halw (ed.). Cairo: Dar Ihya' al-Kutub al-'Arabiyah.

Wehr, H. (1976). A Dictionary of Modern Written Arabic. J. Milton Cowan (ed.). New York-Ithaca: Spoken Language Services, Inc. $3^{\text {rd }}$ edition. 
INTERNATIONAL JOURNAL OF ACADEMIC RESEARCH IN BUSINESS AND SOCIAL SCIENCES

Vol. 8, No. 10, Oct. 2018, E-ISSN: 2222-6990 @ 2018 HRMARS

Al-Zabidi, M. (1989). Ithaf al-sadah al-muttaqin bi sharh Ihya' 'ulum al-din. Beirut: Dar kutub al'Ilmiyah. 